\title{
Jurist-Diction
}

Volume 3 No. 6, November 2020

\section{Pemutusan Hubungan Kerja Dengan Alasan Indisipliner Melalui Aplikasi Whatsapp Messenger}

\author{
Muhammad Ammar Afif \\ ammarvio7@gmail.com \\ Universitas Airlangga
}

How to cite:

Muhammad Ammar Afif,

'Pemutusan Hubungan Kerja

Dengan Alasan Indisipliner

Melalui Aplikasi Whatsapp

Messenger' (2020) Vol. 3 No. 6

November Jurist-Diction.

Histori artikel:

Submit 10 Agustus 2020;

Diterima 7 September 2020;

Diterbitkan 1 November 2020.

DOI:

10.20473/jd.v3i6.22972

\begin{abstract}
Abstrak
Alasan Pemutusan Hubungan Kerja oleh pengusaha terhadap buruh/ pekerja sering kali menimbulkan perselisihan antara pengusaha dengan pihak buruh. Banyak faktor yang memperngaruhi perselisihan tersebut, salah satunya adalah tindakan indisipliner oleh buruh/pekerja yang digunakan sebagai alasan pemutusan hubungan kerja oleh pengusaha. Tindakan indisipliner sendiri dapat terjadi karena beberapa hal seperti buruh/pekerja salah tafsir atas perjanjian kerja, peraturan perusahaan maupun perjanjian kerja bersama, dan dapat juga karena buruh/pekerja sengaja melakukan pelanggaran atas ketentuan tersebut yang telah disepakati oleh para pihak. Terdapat beberapa hal yang harus diperhatikan pengusaha dalam melakukan pemutusan hubungan kerja terhadap buruh karena tindakan indisipliner, seperti prosedur atau ketentuan yang terdapat pada Undang-Undang Ketenagakerjaan. Secara tersirat indisipliner diatur pada pasal 161 Undang-Undang Ketenagakerjan seperti adanya surat peringatan secara berturut turut misalnya. Kemudian dalam hal sarana pemberitahuan pemutusan hubungan kerja, seiring berkembangnya tekhnologi aplikasi pesan singkat WhatsApp Messenger tidak hanya sebagai alat pengirim pesan singkat saja namun dapat dijadikan sarana untuk pemberitahuan PHK oleh pengusaha. Tentu dalam hal ini pengusaha tetap harus mengikuti prosedur pemutusan hubungan kerja dalam tindakannya sesuai Undang-Undang Ketenagakerjaan.

Kata Kunci: Pemutusan Hubungan Kerja; Indisipliner; Pemberitahuan melalui WhatsApp Messenger.
\end{abstract}

\section{Pendahuluan}

Sejak Indonesia merdeka, kita menyadari bahwa pekerjaan adalah kebutuhan setiap warga negara demi dapat memperoleh penghidupan yang layak dan memadai bagi kemanusiaan, sebagai mana yang telah tertera pada ketentuan pasal 27 ayat (2) Undang-Undang Negara Republik Indonesia 1945 yang menyatakan:

"Tiap-tiap warga negara berhak atas pekerjaan dan penghidupan yang layak 
bagi kemanusiaan". ${ }^{1}$

Hubungan industrial antara pekerja dan pengusaha tidak selalu berjalan mulus. Sering kali terjadi perselisihan yang berujung pada pemutusan hubungan kerja atau dapat juga disebut dengan PHK. Putusnya hubungan kerja ini dapat terjadi kapan saja dikarenakan sebab-sebab tertentu. Dalam hubungan kerja para pihak baik buruh maupun pengusaha mempunyai kesempatan yang sama untuk mengakhiri hubungan kerja mereka. Pemutusan hubungan kerja merupakan pengakhiran hubungan kerja karena suatu hal tertentu yang berakibat berakhirnya hak dan kewajiban buruh kepada pengusaha maupun sebaliknya. Dengan berakhirnya hubungan kerja tersebut, pekerja atau buruh tidak lagi mempunyai kewajiban untuk bekerja pada pengusaha dan pengusaha tidak mempunyai kewajiban untuk membayar upah kepada pekerja atau buruh. ${ }^{2}$

Mengenai pemutusan hubungan kerja, ada beberapa cara untuk melakukan pemutusan hubungan kerja yaitu :

a. Pemutusan hubungan kerja oleh majikan;

b. Hubungan kerja putus demi hukum;

c. Hubungan kerja putuskan melalui pengunduran diri pekerja;

d. Pemutusan hubungan kerja oleh pengusaha karena pekerja dianggap mengundurkan diri;

e. Hubungan kerja yang diputus oleh pengusaha;

f. Hubungan kerja yang diputuskan oleh pengadilan;

g. Pemutusan hubungan kerja karena terjadi perubahan status perusahaan melalui penggabungan, peleburan, atau perubahan kepemilikan perusahaan, atas kemauan pengusaha maupun pekerja;

h. Pemutusan hubungan kerja karena kerugian terus menerus selama dua tahun atau force majeur;

i. Pemutusan hubungan kerja karena perusahaan mengalami pailit;

j. Pemutusan Hubungan kerja karena pekerja atau buruh meninggal dunia;

k. Pemutusan hubungan kerja karena memasuki usia pensiun.

Berakhirnya hubungan kerja yang dilakukan melalui pemutusan hubungan kerja oleh perusahaan penyedia lapangan pekerjaan kepada pekerja atau buruhnya merupakan suatu pengakhiran sumber nafkah bagi pekerja dan keluarganya yang hal

\footnotetext{
1 Adrian Sutedy, Hukum Perburuhan Indonesia (Sinar Grafika 2008).[35].

2 Suratman, Pengantar Hukum Ketenagakerjaan Indonesia (Rajawali Pers 2019).[7].
} 
ini dilakukan oleh pengusaha terhadap pekerja atau buruhnya. ${ }^{3}$ Hal ini seharusnya dihindari oleh pengusaha, karena pada hakikatnya Pemutusan Hubungan Kerja atau PHK bagi pengusaha adalah perusahaan akan kehilangan tenaga kerja yang telah mengerti prosedur perusahaannya dan harus mencari kembali pekerja atau buruh untuk menempati posisi pekerja atau buruh yang telah diputus hubungan kerjanya. Pada dasarnya PHK atau Pemutusan Hubungan Kerja merupakan hal yang dilarang. Pasal 151 ayat (1) Undang-Undang Nomor 13 tahun 2003 tentang Ketenagakerjaan menyatakan agar pengusaha, pekerja atau buruh, serikat pekerja atau buruh dan pemerintah untuk mengupayakan agar jangan terjadi pemutusan hubungan kerja. ${ }^{4}$ Dari segi perkembangan teknologi komunikasi yang mempunyai pengaruh dan dampak bagi perilaku dan pola hidup masyarakat secara keseluruhan, berbagai informasi dan komunikasi kini dapat disajikan melalui hubungan jarak jauh dan siapapun yang berkehendak untuk melakukan transaksi, cukup dilakukan melalui perangkat telekomunikasi. ${ }^{5}$ Dengan perkembangan teknologi dan informasi dan kegiatan di ruang siber, banyak sekali suatu hal yang sebelumnya tidak dapat dilakukan menjadi dapat dilakukan. Pada 24 Februari 2009, Jan Koum dan Brian Acton mendirikan sebuah platform bernama WhatsApp Messenger, WhatsApp Messenger adalah aplikasi pesan lintas platform yang memungkinkan kita bertukar pesan menggunakan data internet dengan mudah dan cepat. Kini dalam prakteknya aplikasi WhatsApp Messenger digunakan sebagai sarana berbagai kegiatan penting, seperti bertransaksi jual beli,sewa menyewa dan berbagai kegiatan yang bersifat keperdataan yang menimbulkan hak dan kewajiban bagi para pihak. Seperti melakukan perjanjian kerja melalui aplikasi WhatsApp Messenger, Perjanjian kerja yang dilakukan melalui percakapan elektronik ini berdasarkan Pasal 5 ayat (1) Undang-Undang Nomor 11 Tahun 2008 tentang Informasi dan Transaksi

\footnotetext{
${ }^{3}$ Aloysius Uwiyono et al, Asas-Asas Hukum Perburuhan, Edisi 2, Cet. 3 (Rajawali Pers 2018).[142].

${ }^{4}$ Lanny Ramli, Hukum Ketenagakerjaan (Airlangga University Pers 2008).[31].

${ }^{5}$ Lathifah Hanim, 'Pengaruh Perkembangan Teknologi Informasi Terhadap Keabsahan Perjanjian dalam Perdagangan secara Elektronik (E-Commerce) di Era Globalisasi' (2011) 11 Jurnal Dinamika Hukum.[60]
} 
sebagaimana diubah dalam Undang-Undang Nomor 19 Tahun 2016 tentang Perubahan atas Undang-Undang Nomor 11 Tahun 2008 tentang Informasi dan Transaksi Elektronik, termasuk ke dalam informasi elektronik yang merupakan alat bukti hukum yang sah. Maka perjanjian kerja tersebut tetap mengikat dan mempunyai kekuatan hukum walaupun tidak sekuat apabila perjanjian kerja dilakukan secara tertulis. Seperti sebagaimana yang telah diatur pada pasal 52 ayat (1) tahun 2003 UU Ketenagakerjaan bahwa ada beberapa unsur dasar Perjanjian Kerja yang harus dipenuhi dan mengikat bagi pengusaha dan pekerjanya, antara lain:

1. Kesepakatan para pihak;

2. Kecakapan dalam melakukan perbuatan hukum;

3. Adanya pekerjaan yang diperjanjikan; dan

4. Pekerjaan yang diperjanjikan tidak boleh bertentangan dengan ketertiban umum, kesusilaan, dan peraturan perundang-undangan yang berlaku.

Atau dapat disimpulkan bahwa yang harus ada pada kesepakatan perjanjian kerja adalah:

1. Syarat-syarat kerja;

2. Hak pekerja atau buruh dan pengusaha; dan

3. Kewajiban pekerja atau buruh dan pengusaha.

Tetapi pada saat ini terdapat beberapa kasus antara lain seperti Pemutusan Hubungan Kerja atau PHK oleh pengusaha terhadap buruh atau pekerjanya yang sarana pemberitahuannya melalui aplikasi WhatsApp dan pengusaha yang melakukan PHK secara sepihak karena buruh / pekerja dianggap telah melakukan tindakan indisipliner. Hal tersebut terjadi pada Achmad Gojali, seorang salesman di perusahaan distributor air minum Nestle, PT. Akasha Wira International. Ia diberhentikan atau diputus hubungan kerjanya sejak 18 Desember 2017, yang dimana keputusan perusahaan tersebut Ia dapatkan melalui pesan singkat WhatsApp Messenger atasannya kepada dirinya. ${ }^{6}$ Achmad Gojali diputus hubungan kerjanya karena diduga telah lalai dalam mengantisipasi kekurangan ketersediaan

\footnotetext{
${ }^{6}$ Buruhonline, 'Dipecat via WhatsApp, Seorang Salesman Gugat Distributor Nestle', $<$ https:// buruh-online.com/2019/03/dipecat-via-whatsapp-seorang-salesman-gugat-distributor-nestle.html> accesed 27 Januari 2020.
} 
air di Malang. Padahal Achmad Gojali hanya bekerja untuk mengurus distribusi air minum Nestle di Surabaya, Sidoarjo dan Madura. Tindakan pemberhentian yang dilakukan PT. Akasha Wira International merupakan tindakan pemutusan hubungan kerja sepihak dan tanpa prosedur yang telah diatur dalam ketentuan perundang-undangan ketenagakerjaan yang berlaku dan ada satu kasus lagi yaitu kasus dengan nomor perkara 182/Pdt.Sus-PHI/2019/PN.Bdg antara Royke selaku buruh/pekerja sekaligus penggugat dengan tergugat CV. Unity Indo Sukses (Badan Usaha dari Verde Resto and Lounge). Royke merupakan koordinator keamanan diperusahaan tersebut sejak Juni 2012 atau sudah bekerja selama 7 tahun 1 bulan. Pada bulan Oktober 2018 anggota dari Royke tidak sengaja melakukan kesalahan saat hendak memarkirkan mobil inventaris perusahaan, anggota keamanan tersebut tidak sengaja menabrak yang membuat mobil tersebut rusak. Penggugat mencoba memastikan perbuatan tersebut kepada Tergugat namun tidak pernah mendapatkan jawaban yang memuaskan. Hingga puncaknya pada 27 Oktober 2018 Penggugat tidak mendapatkan upah sebagaimana biasanya pada tanggal 26 atau 27 tiap bulannya merupakan jadwal dimana Penggugat mendapatkan upah. Penggugat mencoba menghubungi pihak tergugat yang akhirnya pada 29 Oktober 2018 mendapat upah dari Tergugat. Tetapi setelah penggugat menerima upah tersebut, melalui pesan WhatsApp Messenger Tergugat memberitahukan bahwa upah yang diterima pada 29 Oktober 2018 tersebut merupakan upah terakhir yang diterima Penggugat dan Penggugat dinyatakan tidak bekerja lagi pada Tergugat dikarenakan Penggugat dianggap kurang kontrol pada anggotanya yang menyebabkan kerugian berupa kerusakan pada mobil inventaris Tergugat. Penggugat disini melalui kuasa hukumnya menyatakan bahwa tindakan Tergugat merupakan tidak sah atau batal demi hukum karena tanpa adanya perundingan, adanya peringatan, dan tanpa adanya penetapan dari lembaga penyelesaian perselisihan hubungan industrial yang bertentangan pada Pasal 151 ayat (2) dan ayat (3) Undang-undang Ketenagakerjaan. Namun pada kasus tersebut gugatannya ditolak karena cacat formil yang dimana yang digugat oleh Penggugat merupakan Badan Usaha berbentuk CV yang mana bukanlah subjek hukum. Kemudian hingga kini pada tahun 2020 kasus tersebut 
belum gugat lagi karena adanya faktor finansial dari pihak Penggugat. Dalam melakukan pemutusan hubungan kerja dalam hal buruh atau pekerja melakukan kesalahan atau lalai yang menyebabkan kerugiaan pada perusahaan tersebut, harus didahului dengan surat peringatan, kemudian apabila masih terjadi kesalahan maka perusahaan dapat melakukan upaya penyelesaian melalui lembaga Pengadilan Hubungan Industrial terlebih dahulu hingga terjadi atau adanya keabsahan suatu pemutusan hubungan kerja. Perselisihan tentang Pemutusan Hubungan Kerja atau PHK ini dapat dikategorikan ke dalam jenis perselisihan hubungan industrial sebagaimana telah diatur dalam Pasal 2 Undang - undang Nomor 2 Tahun 2004 tentang Penyelesaian Perselisihan Hubungan Industrial. Yang dimaksud dengan perselisihan hubungan industrial adalah perbedaan pendapat yang mengakibatkan pertentangan antara pengusaha dan gabungan pengusaha dengan pekerja atau buruh atau serikat pekerja atau serikat buruh karena adanya perselisihan mengenai hak, perselisihan kepentingan, perselisihan pemutusan hubungan kerja, dan perselisihan antar serikat pekerja atau buruh dalam satu perusahaan.

Pasal 151 UU Ketenagakerjaan menjelaskan bahwa pekerja dan pengusaha harus berusaha semaksimal mungkin menghindari pemutusan hubungan kerja. Jika memang tidak bisa untuk dihindari, maka pekerja dan pengusaha harus berunding untuk mencari kesepakatan. Namum bila hasil perundingan itu masih tidak menemui titik temu, maka pemutusan hubungan kerja baru bisa dilaksanakan setelah ada penetapan dari lembaga penyelesaian perselisihan hubungan industrial. Selain itu, telah diatur prosedur untuk melakukan pemutusan hubungan kerja dalam Pasal 161 ayat (1) UU Ketenagakerjaan yang menyatakan bahwa pengusaha dapat melakukan pemutusan hubungan kerja, setelah kepada pekerja atau buruh yang bersangkutan diberikan surat peringatan pertama, kedua dan ketiga secara berturut-turut.

Dari penjelasan diatas pemutusan hubungan kerja tidak dapat dilakukan dengan cepat dan semudah mengirim pesan melalui aplikasi WhatsApp Messenger, pengusaha perlu mengikuti prosedur untuk dapat melakukan pemutusan hubungan kerja dengan buruh atau pekerjanya. Maka dari itu penulis akan membahas tentang pemutusan hubungan kerja oleh pengusaha kepada buruh atau pekerjanya melalui 
aplikasi pesan singkat WhatsApp Messenger yang harus terlebih dahulu mengikuti prosedur sesuai ketentuan perundang-undangan yang ada dan akibat hukum terhadap tindakan pengusaha kepada buruhnya atas pemutusan hubungan kerja secara sepihak yang dilakukan sesuai prosedur yang ada.

\section{Prosedur Pemutusan Hubungan Kerja Atas Kehendak Pengusaha}

Pemutusan Hubungan Kerja merupakan pengakhiran suatu perjanjian kerja yang mengakibatkan berakhirnya hak dan kewajiban para pihak yang telah disepakati pada perjanjian kerja. Dalam melakukan pemutusan hubungan kerja tidak dapat dilakukan dengan seketika saja, perlu prosedur untuk dapat melakukannya baik itu pemutusan hubungan kerja oleh pengusaha maupun pemutusan hubungan kerja oleh kemauan buruh itu sendiri. Namun pada realitanya yang banyak mengakhiri suatu hubungan kerja adalah atas kehendak pengusaha atau majikan dan bukan atas kehendak pekerja atau buruh. Berakhirnya hubungan kerja bagi pekerja atau buruh berarti kehilangan suatu mata pencaharian dan merupakan awal dari kesengsaraan bagi pekerja tersebut.

Pemutusan hubungan kerja atau PHK sebenarnya merupakan hal yang dilarang. Hal tersebut telah dijelaskan pada pasal 151 Undang-Undang Ketenagakerjaan, yang berbunyi: Pengusaha, pekerja atau buruh, serikat pekerja atau serikat buruh, dan pemerintah, dengan segala upaya harus mengusahakan agar jangan terjadi pemutusan hubungan kerja.

Perlu dipahami bahwa maksud dari segala upaya pada pasal 151 ayat (1) Undang-Undang Ketenagakerjaan adalah kegiatan-kegiatan yang positif yang selanjutnya dapat mengurangi dan menghindari terciptanya suatu pemutusan -hubungan kerja. Para pihak dapat mengupayakan dengan beberapa cara seperti melakukan pengaturan waktu kerja, perbaikan metode kerja, dan pengusaha dapat memberikan pembinaan kepada pekerja. Apabila setelah upaya-upaya tersebut telah dilakukan tetapi pemutusan hubungan kerja tidak dapat dihindari, maka pengusaha dengan buruh ataupun para pihak yang bersangkutan wajib merundingkannya terlebih dahulu. 
Setiap pengusaha pasti memiliki alasan tersendiri untuk melakukan pemutusan hubungan kerja dengan pekerja atau buruhnya yang bekerja pada perusahaannya. Pasal 4 Konvensi ILO nomor 158 tentang pemutusan hubungan kerja mensyaratkan bahwa pengusaha yang akan melakukan pemutusan hubungan kerja kepada buruh atau pekerjanya harus mempunyai alasan yang sah untuk melakukan pemutusan hubungan kerja tersebut yang berkaitan dengan kemampuan pekerja maupun persyaratan operasional perusahaan. ${ }^{7}$ Hal tersebut menunjukan bahwa syarat pengusaha melakukan pemutusan hubungan kerja dengan dasar alasan yang sah merupakan prinsip dasar dari Konvensi ILO Nomor 158 tentang Pemutusan Hubungan Kerja. ${ }^{8}$ Pengusaha dalam melakukan PHK selain harus menyertakan bukti harus juga terlebih dahulu memberi surat peringatan kepada buruh yang akan pengusaha putus hubungan kerjanya baik surat peringatan berturutturut maupun surat peringatan pertama dan terakhir sesuai mekanisme dalam melakukan pemutusan hubungan kerja, kecuali telah diatur lain pada perjanjian kerja, peraturan perusahaan atau perjanjian kerja bersama, dan ada pula PHK yang tidak membutuhkan surat peringatan seperti karena perusahaan pailit, perusahaan bangkrut, pekerja meninggal dunia, dan lain lain. Untuk surat peringatan sesuai dengan ketentuan pada pasal 161 ayat (1) Undang-Undang Ketenagakerjaan yang berbunyi:

"Dalam hal pekerja atau buruh melakukan pelanggaran ketentuan yang diatur dalam perjanjian kerja, peraturan perusahaan atau perjanjian kerja bersama, pengusaha dapat melakukan pemutusan hubungan kerja, setelah kepada pekerja atau buruh yang bersangkutan diberikan surat peringatan pertama, kedua, dan ketiga secara berturut-turut".

Dari ketentuan tersebut, pengusaha harus memberi surat peringatan kepada pekerja atau buruh sebanyak tiga kali, surat peringatan yang dimaksud hanya berlaku untuk jangka waktu 6 (enam) bulan untuk tiap peringatannya, kecuali dalam

\footnotetext{
${ }^{7}$ Budi Santoso, "Perlindungan Pekerja Terhadap Pemutusan Hubungan Kerja Atas Inisiatif Pengusaha Berdasarkan Konvensi ILO Nomor 158 tahun 1982” (2013), 3 Jurnal Hukum PRIOR'S, [30].

${ }^{8}$ ILO,'Note on Convention No. 158 and Recommendation No. 166 concerning termination of employment', <http://wwwilo.ora/wcmsp5/aroups/publicl@ednorm/@normes/documents/ meetingdocument/wcms100768.pdf>, accesed 9 Maret 2020.
} 
perjanjian kerja atau peraturan perusahaan mengatur secara berbeda. Pada perkara nomor 182/Pdt.Sus-PHI/2019/PN.Bdg seorang buruh yang bernama Royke diputus hubungan kerjanya tanpa prosedur yang salah satunya adalah pemberian surat peringatan kepadanya dan pengusaha tidak melakukan upaya pada pasal 151 ayat (1) dan ayat (2) Undang-Undang Ketenagakerjaan. Pengusaha menganggap Royke telah melakukan tindakan yang merugikan perusahaan, apabila Royke terbukti bersalah karena melakukan tindakan indisipliner maka, setidaknya keputusan pengusaha memberikan surat peringatan sesuai pasal 161 Undang-undang Ketenagakerjaan terlebih dahulu, lalu selanjutnya buruh dapat diberi pengawasan dalam bekerja dan bimbingan agar tidak melakukan tindakan indisipliner kembali.

Prosedur pemutusan hubungan kerja selain harus memberi surat peringatan sesuai pasal 161 Undang-Undang Ketenagakerjaan sebagai bentuk upaya atas dasar dilaksanakannya pasal 151 Undang-Undang Ketenagakerjaan untuk menghindari adanya pemutusan hubungan kerja juga dapat berdasar atas perjanjian kerja, peraturan perusahaan atau perjanjian kerja bersama. Perjanjian Kerja adalah perjanjian yang menjelaskan tentang kerja, dengan adanya perjanjian kerja maka timbul adanya hak dan kewajiban antara pengusaha dengan buruh untuk melakukan suatu pekerjaan. ${ }^{9}$ Dalam tiap perjanjian kerja setiap perusahaan mempunyai ketentuan yang berbeda beda sesuai kebijakan dan kesepakatan para pihak, hal itu termasuk pula mengenai pemutusan hubungan kerja. Peraturan perusahaan merupakan peraturan yang dibuat secara tertulis oleh pengusaha yang memuat syarat kerja dan tata tertib dalam suatu perusahaan. Dan perjanjian kerja bersama atau PKB adalah perjanjian hasil dari perundingan antara serikat pekerja atau buruh yang tercatat pada suatu instansi yang bertanggung jawab di bidang ketenagakerjaan dengan pengusaha ataupun beberapa pengusaha yang memuat syarat kerja, hak dan kewajiban para pihak.

Jadi pada dasarnya prosedur pemutusan hubungan kerja oleh pengusaha dikarenakan pekerja melakukan pelanggaran atas disiplin kerja harus sesuai dengan perjanjian kerja, peraturan perusahaan, atau perjanjian kerja bersama

\footnotetext{
9 Lanny Ramli,Op.Cit.[23].
} 
yang dimana setiap perusahaan bisa jadi mempunyai aturan yang berbeda dalam hal mengkategorikan suatu pelanggaran dan disiplin kerja. Dan tidak selalu kesalahan yang dilakukan pekerja merupakan kesalahan berat yang menyebabkan dapat dilakukannya PHK dengan alasan tersebut. Ada kalanya pengusaha dapat memberikan surat peringatan kepada pekerja apabila pekerja melakukan kesalahan ringan ataupun sedang, yang biasanya membuat pengusaha menggunakan alasan buruh atau pekerja telah indisipliner yaitu karena telah melanggar peraturan perusahaan, perjanjian kerja maupun perjanjian kerja bersama yang telah disepakati oleh para pihak sebelumnya. Selanjutnya apabila dari pemutusan hubungan kerja tersebut telah selesai dan menemui kesepakatan, maka pemutusan hubungan kerja ini perlu adanya penetapan agar dikemudian hari tidak terjadi perselisihan ataupun sengketa yang dapat merugikan salah satu bahkan kedua belah pihak, maka dari itu pengusaha dapat meminta penetapan pemutusan hubungan kerja kepada Dinas Tenaga Kerja (Disnaker) pada kota tempat buruh itu bekerja.

\section{Pemutusan Hubungan Kerja Karena Buruh Indisipilner}

Indisipliner adalah perbuatan melanggar suatu disiplin pada ketentuan yang telah di sepakati oleh para pihak, sementara pada konteks perburuhan, indisipliner adalah perbuatan buruh/pekerja yang melanggar ketentuan pada Peraturan Perusahaan, Perjanjian Kerja, dan Perjanjian Kerja Bersama. Pada beberapa kasus dalam perburuhan, tindakan indisipliner sendiri dapat dikarenakan beberapa hal, seperti buruh/pekerja salah tafsir atas suatu disiplin kerja maupun buruh/ pekerja memang sengaja melakukan tindakan indisipliner tersebut. Dari tindakan indisipliner ini pengusaha dapat memberikan hukuman maupun sanksi ataupun peringatan kepada buruh/pekerja atas pelanggaran tertentu yang telah diatur pada perjanjian kerja, peraturan perusahaan maupun perjanjian kerja bersama.

Jika dilihat bahwa indisipliner tidak diatur pada Undang-Undang Nomor 13 Tahun 2003 tentang Ketenagakerjaan, tetapi secara tersirat indisipliner terdapat pada Undang-Undang Nomor 13 Tahun 2003 tentang Ketenagakerjaan, yaitu pada Pasal 161 Undang-Undang Ketenagakerjaan: 
1. Dalam hal pekerja/buruh melakukan pelanggaran ketentuan yang diatur dalam perjanjian kerja, peraturan perusahaan atau perjanjian kerja bersama, pengusaha dapat melakukan pemutusan hubungan kerja, setelah kepada pekerja/buruh yang bersangkutan diberikan surat peringatan pertama, kedua, dan ketiga secara berturut-turut.

2. Surat peringatan sebagaimana dimaksud dalam ayat (1) masing-masing berlaku untuk paling lama 6 (enam) bulan, kecuali ditetapkan lain dalam perjanjian kerja, peraturan perusahaan atau perjanjian kerja bersama

Dari penjelasan Pasal 161 ayat (2) Undang-undang Ketenagakerjaan, bahwa pengusaha dalam memberikan surat peringatan kepada pekerja cara penerbitannya mengikuti pada ketentuan yang telah disepakati oleh para pihak pada perjanjian kerja, peraturan perusahaan maupun perjanjian kerja bersama. Selain itu pengusaha biasanya mengenakan sanksi atas tindakan indisipliner pekerja/buruh tersebut seperti:

1. Peringatan secara tertulis;

a. Peringatan pertama (berlaku 6 bulan setelah peringatan diberitahukan)

b. Peringatan kedua (berlaku 6 bulan setelah peringatan diberitahukan)

c. Peringatan ketiga (berlaku 6 bulan setelah peringatan diberitahukan)

d. Peringatan pertama sekaligus terakhir. Biasanya diterapkan pengusaha kepada buruh apabila buruh melakukan pelanggaran berat.

2. Mutasi pekerja;

3. Penundaan kenaikan pangkat atau jabatan;

4. Pencabutan jabatan; dan

5. Pemutusan Hubungan Kerja

Bahkan selain 5 (lima) poin diatas beberapa perusahaan juga menerapkan sanksi atas indisipliner yang beragam sesuai ketentuan yang disepakati pada perjanjian kerja, peraturan perusahaan, dan perjanjian kerja bersama

Jika dilihat beberapa perusahaan ada yang memberikan sanksi terberat atas tindakan indisipliner adalah Pemutusan Hubungan Kerja (PHK), hal ini seperti pada kasus yang telah diuraikan pada latar belakang penulisan skripsi ini, pada perkara nomor 182/Pdt.Sus-PHI/2019/PN.Bdg antara Royke dengan CV. Unity Indo Sukses (Badan Usaha dari Verde Resto an Lounge). Pengusaha menghentikan Royke sebagai koordinator keamanan karena dinilai telah melanggar disiplin kerja 
yang merugikan benda inventaris perusahaan yaitu berupa mobil. Pada saat itu anggota dari Royke hendak memarkirkan mobil inventaris perusahaan tetapi tidak sengaja menabrak yang membuat kerusakan pada mobil tersebut, hal ini di nilai oleh perusahaan bahwa Royke sebagai pekerja/buruh telah melakukan tindakan indisipliner karena kurang kontrol kepada anggotanya. Namun sayangnya pada saat melakukan PHK, perusahaan melakukannya tanpa prosedur seperti surat peringatan dan adanya penetapan, serta hak hak pekerja untuk mendapat pesangon sesuai pada Pasal 156 ayat (2), (3), dan (4) Undang-Undang Ketenagakerjaan pun belum dibayarkan oleh perusahaan. Royke sebagai pekerja masih sempat menerima gaji pada 29 Oktober 2019, tetapi pada percakapan melalui WhatsApp Messenger antara Royke dengan Pengusaha didapati bahwa gaji yang diterima pada 29 Oktober tersebut merupakan gaji terakhir dan Royke dinyatakan tidak bekerja lagi pada CV. Unity Indo Sukses dikarenakan Royke sebagai koordinator keamanan dianggap kurang kontrol sehingga menyebabkan anggota dari Royke melakukan kesalahan yang mengakibatkan kerusakan pada mobil inventaris perusahaaan.

\section{WhatsApp Sebagai Media Pemberitahuan Pemutusan Hubungan Kerja}

Siapa yang sangka pada era modern ini dengan perkembangan teknologi yang pesat, WhatsApp Messanger aplikasi yang diperuntukan untuk melakukan pesan singkat antar penggunanya dapat dimanfaatkan menjadi sarana pemberitahuan pemutusan hubungan kerja. Pasal 1 angka 2 Undang Undang ITE menjelaskan bahwa Transaksi Elektronik adalah transaksi yang dilakukan secara elektronik dengan menggunakan komputer, jaringan komputer, atau media elektronik lainnya. Kemudian dalam trasnsaksi elektronik yang terjadi ini akan melahirkan suatu informasi elektronik. Informasi Elektronik berdasarkan pasal 1 angka 1 UU ITE berbunyi:

"Informasi Elektronik merupakan satu atau sekumpulan data elektronik, termasuk tetapi tidak terbatas pada tulisan, suara, gambar, peta, rancangan, foto, electronic data interchange (EDI), surat elektronik (electronic mail atau $e$-mail), telegram, teleks, telecopy atau sejenisnya, huruf, tanda, angka, kode akses, simbol, atau perforasi yang telah diolah yang memiliki arti atau dapat dipahami oleh orang yang mampu memahaminya". 
Dari pasal tersebut, WhatsApp Messengger dapat di kategorikan ke dalam informasi elektronik, mengenai ketentuan tersebut pasal 5 Undang-Undang ITE memiliki ketentuan sebagai berikut:

1. Informasi Elektronik dan/atau Dokumen Elektronik dan/atau hasil cetaknya merupakan alat bukti hukum yang sah;

2. Informasi Elektronik dan/atau Dokumen Elektronik dan/atau hasil cetaknya sebagaimana dimaksud pada ayat satu (1)merupakanperluasan dari alat bukti yang sah sesuai dengan Hukum Acara yang berlaku di Indonesia;

3. Informasi Elektronik dan/atau Dokumen Elektronik dinyatakan sah apabila menggunakan Sistem Elektronik sesuai dengan ketentuan yang diatur dalam Undang-Undang ini;

4. Ketentuan mengenai Informasi Elektronik dan/atau Dokumen Elektronik sebagaimana dimaksud pada ayat (1) tidak berlaku untuk:

a. surat yang menurut Undang-Undang harus dibuat dalam bentuk tertulis; dan

b. surat beserta dokumennya yang menurut Undang-Undang harus dibuat dalam bentuk akta notaril atau akta yang dibuat oleh pejabat pembuat akta.

Pengertian ketentuan pada pasal 5 UU ITE, keberadaan informasi elektronik atau dokumen elektronik diakui sebagai alat bukti yang sah untuk memberikan kepastian hukum terhadap penyelenggaraan sistem elektronik dan transaksi elektronik, khususnya pada hal pembuktian yang berakaitan dengan perbuatan hukum melalui WhatsApp Messenger. Tetapi pada suatu kasus tidak hanya pemberitahuan saja yang dilakukan melalui WhatsApp Messengger, melainkan penyampaian atas penetapan pemutusan hubungan kerja juga dilakukan melalui media WhatsApp. Kejadian tersebut terjadi pada Royke Puri wardaya yang mendapat pemberitahuan PHK melalui WhatsApp Messenger. ${ }^{10}$ Dari kasus tersebut, didapati Royke mendapatkan pesan tersebut secara tiba tiba tanpa didahului prosedur maupun mekanisme dalam pemutusan hubungan kerja. Hal tersebut menjadi salah satu dasar gugat Royke kepada pengusaha CV.Unity Indo Sukses karena telah menyalahi aturan pada ketentuan pasal 151 ayat (2) dan (3) Undang-Undang Ketenagakerjaan. Penjelasan pasal 5 ayat (1) Undang-Undang tentang Informasi dan Transaksi Elektronik menjelaskan bahwasannya keberadaan informasi elektronik dan/atau dokumen

\footnotetext{
${ }^{10}$ Buruhonline, 'Pemberitahuan PHK Lewat WhatsApp Pekerja Tuntut Pesangon', $<$ https:// buruh-online.com/2019/08/pemberitahuan-phk-lewat-whatsapp-pekerja-tuntut-pesangon.html $>$, accesed 13 Maret 2020.
} 
elektronik mengikat dan diakui sebagai alat bukti yang sah untuk memberikan kepastian hukum terhadap penyelengaraan sistem elektronik dan transaksi elektronik, terutama dalam hal pembuktian yang berkaitan dengan perbuatan hukum melalaui sistem elektronik. Namun pasal 5 ini dalam perihal PHK juga harus didampingi prosedur-prosedur serta alasan-alasan PHK sesuai pada ketentuan Undang-Undang Ketenagakerjaan. Maka dapat dikatakan sarana pemberitahuan melalui WhatsApp Messenger tidak mengurangi keabsahan yang telah ditetapkan dan sah sepanjang pengusaha dalam melakukan PHK telah mengikuti prosedur pada Undang-Undang Ketenagakerjaan maupun PP,PK, dan PKB antara para pihak. Namun apabila Pengusaha tidak melakukan prosedur-prosedur yang ada dalam melakukan PHK terhadap pekerjanya yang menyebabkan PHK tersebut menjadi batal demi hukum. Pengusaha yang melakukan pemberitahuan melalui WhatsApp Messenger merupakan salah satu bentuk efisiensi dalam melakukan pekerjaan, terlebih misalkan yang di putus hubungan kerjanya oleh pengusaha tidak hanya satu dua melainkan PHK masal yang bisa mencapai 50\% dari total pekerja di perusahaan tersebut. Maka disamping membuat surat pemberitahuan secara tertulis dan diberikan secara langsung kepada pekerja, pengusaha juga dapat mengirimkan surat atau penetapan tersebut dalam bentuk soft file melalui electronic mail maupun WhatsApp Messengger, karena pada dasarnya hal tersebut tidak ada aturan mengenai larangan pemberitahuan PHK melalui media e-mail, WhatsApp Messenger, dan pesan singkat lainnya untuk memudahkan penyampaian informasi.

\section{Kesimpulan}

Bahwa keabsahan pemutusan hubungan kerja yang dilakukan oleh pengusaha terhadap buruh indisipliner yang sarana pemberitahuannya melalui WhatsApp Messenger adalah sah sepanjang mengikuti prosedur yang telah diatur pada UndangUndang Ketenagakerjaan maupun ketentuan pada perjanjian kerja, peraturan perusahaan maupun perjanjian kerja bersama. Maka dari itu sarana pemberitahuan menggunakan WhatsApp Messenger tidak mengurangi keabsahan dari pemutusan hubungan kerja sepanjang sesuai prosedur. 


\section{Daftar Bacaan}

\section{Buku}

Adrian Sutedy, Hukum Perburuhan Indonesia (Sinar Grafika Jakarta 2008).

Suratman, Pengantar Hukum Ketenagakerjaan Indonesia (Rajawali Pers 2019).

Aloysius Uwiyono, Asas-Asas Hukum Perburuhan Edisi Revisi (Rajawali Pers 2018).

Lanny Ramli, Hukum Ketenagakerjaan, (Airlangga University Pers,Surabaya 2008).

\section{Jurnal}

Lathifah Hanim, 'Pengaruh Perkembangan Teknologi Informasi Terhadap Keabsahan Perjanjian dalam Perdagangan secara Elektronik (E-Commerce) di Era Globalisasi' (2011),11 Jurnal Dinamika Hukum.

Budi Santoso, 'Perlindungan Pekerja Terhadap Pemutusan Hubungan Kerja Atas Inisiatif Pengusaha Berdasarkan Konvensi ILO Nomor 158 tahun 1982' (2013), 3 Jurnal Hukum PRIOR’S.

\section{Perundang-undangan}

Undang-Undang Dasar Negara Republik Indonesia Tahun 1945.

Undang-Undang Nomor 13 Tahun 2003 tentang Ketenagakerjaan (Lembaran Negara Tahun 2003 Nomor 39, Tambahan Lembaran Negara Nomor 4279).

Undang-Undang Nomor 2 Tahun 2004 tentang Penyelesaian Perselisihan Hubungan Industrial (Lembaran Negara Tahun 2004 Nomor 6, Tambahan Lembaran Negara Nomor 4356).

Undang-Undang Nomor 19 Tahun 2016 tentang perubahan atas Undang-Undang Nomor 11 Tahun 2008 tentang Informasi dan Transaksi Elektronik (Lembaran Negara Republik Indonesia Tahun 2016 Nomor 251, Tambahan Lembaran Negara Republik Indonesia Nomor 5952). 
2308

Muhammad Ammar: Pemutusan Hubungan Kerja

--halaman ini sengaja dibiarkan kosong-- 